\title{
Risk Assessment and Safety of Technosphere Objects and Urban Territories for Siberia and Arctic
}

\author{
$\underline{\text { Ulyana Ivanova }}^{1,2}$, Vladimir Moskvichev ${ }^{1,2}$ \\ ${ }^{1}$ Institute of computational technologies SB RAS,660049, Krasnoyarsk, Russia \\ ${ }^{2}$ Siberian Federal University,660041, Krasnoyarsk, Russia
}

doi: doi: https://doi.org/10.21467/abstracts.93.19

\begin{abstract}
A BST RA CT
The Russian Federation has a huge territory, large part which is occupied by Siberia and Arctic. These regions have a strategically important economic potential for country. On these territories are concentrated large quantity of minerals (lead, platinum, coal, nickel, oil, gas, copper, gold, etc.) so the country's sustainable development is connected with development and successfully functioning of Siberia and Arctic. Until 2020, there were two standards "Strategy socially-and-economically developed of Siberia" and "Strategy of developed for the Arctic zone and provide national safety" acted. These standards presented points for developing, justifying and realizing for events to dangers minimize by using risk-oriental approach. Hazards identification, risk calculation, analysis and minimization are base for sustainable development any territory. A territory is complex socio-natural-technogenic (S-N-T) system which is exposed of different risks.

When we analyze the S-N-T system of the Siberian Federal district, it can be noted that geological and landscape features affect the occurrence of dangerous natural situations, and the developed industry and transport infrastructure has a negative impact on technosphere, environmental and social safety. The analysis of regions that are part of the SFD showed the Krasnoyarsk territory, Irkutsk, Omsk, and Kemerovo regions make the largest contribution to emergency statistics.
\end{abstract}

The paper analyzes man-made hazards for example of a large industrial region - the Krasnoyarsk territory, which includes various climatic zones. The following administrative-territorial units belong to the Arctic zone of the Krasnoyarsk territory: Taimyrsky Dolgano-Nenetskiy district, Norilsk, and part of Turukhansky district. The economic potential for these areas is associated with the fuel industry, metallurgy, oil and gas production and mining (manganese ores, brown coal, etc.).For these territories are characterized following potential risks: fires and explosions, accidents on life systems, accidents on air, water and land transports, accidents on hydraulic structures and accidents with the release of chemically dangerous substances. The remaining municipalities in the Krasnoyarsk territory belong to the territories of Siberia. The main industries of these municipalities are related to energy, logging, timber processing, mechanical engineering and mining (coal, gold, etc.), and potential risks are: fires, major roads accidents, accidents on life systems, collapse of technical structures, accidents with the release of radioactive and chemical dangers substances.

The figure 1 shows a map of the vulnerability of the territory and individual risk from man-made accidents for the Krasnoyarsk territory for the period 2007-2017. The calculation was made by using official data from the Ministry of emergency situations to Russia. The following results were obtained as part of the work:

1. Algorithms for assessing the vulnerability of the territory and individual risk by using statistical analysis are defined

2. The values of individual risks from technogenic accidents for the Krasnoyarsk territory were obtained.

(C) 2020 Copyright held by the author(s). Published by AIJR Publisher in "Abstracts of The Second Eurasian RISK-2020 Conference and Symposium" April 12- 19, 2020, Tbilisi, Georgia. Jointly organized by AMIR Technical Services LLC, Georgian Technical University, Institute of Geography (Kazakhstan) and Russian Institute of Petroleum Geology and Geophysics.

DOI: $10.21467 /$ abstracts.93 
The Second Eurasian RISK-2020 Conference and Symposium

3. High-risk territories that are large industrial cities such as Krasnoyarsk, Norilsk and Achinsk are determined by the level of technogenic danger. They are characterized by the presence of dangerous production, critical and strategically important objects. On the one hand, this is the economic potential of the Krasnoyarsk territory, on the other hand, it leads to major technogenic accidents.

Siberia and the Arctic are unique natural zones, so the development of industry in these territories should take into account all the dangerous factors and risks. The consumer attitude that has been observed in recent decades can lead to natural, man-made and social disasters, and as a result, to the decline of the economy for the whole country. There is a need for more detailed risk analysis at different levels (national, regional, municipal, facility) for effective management.
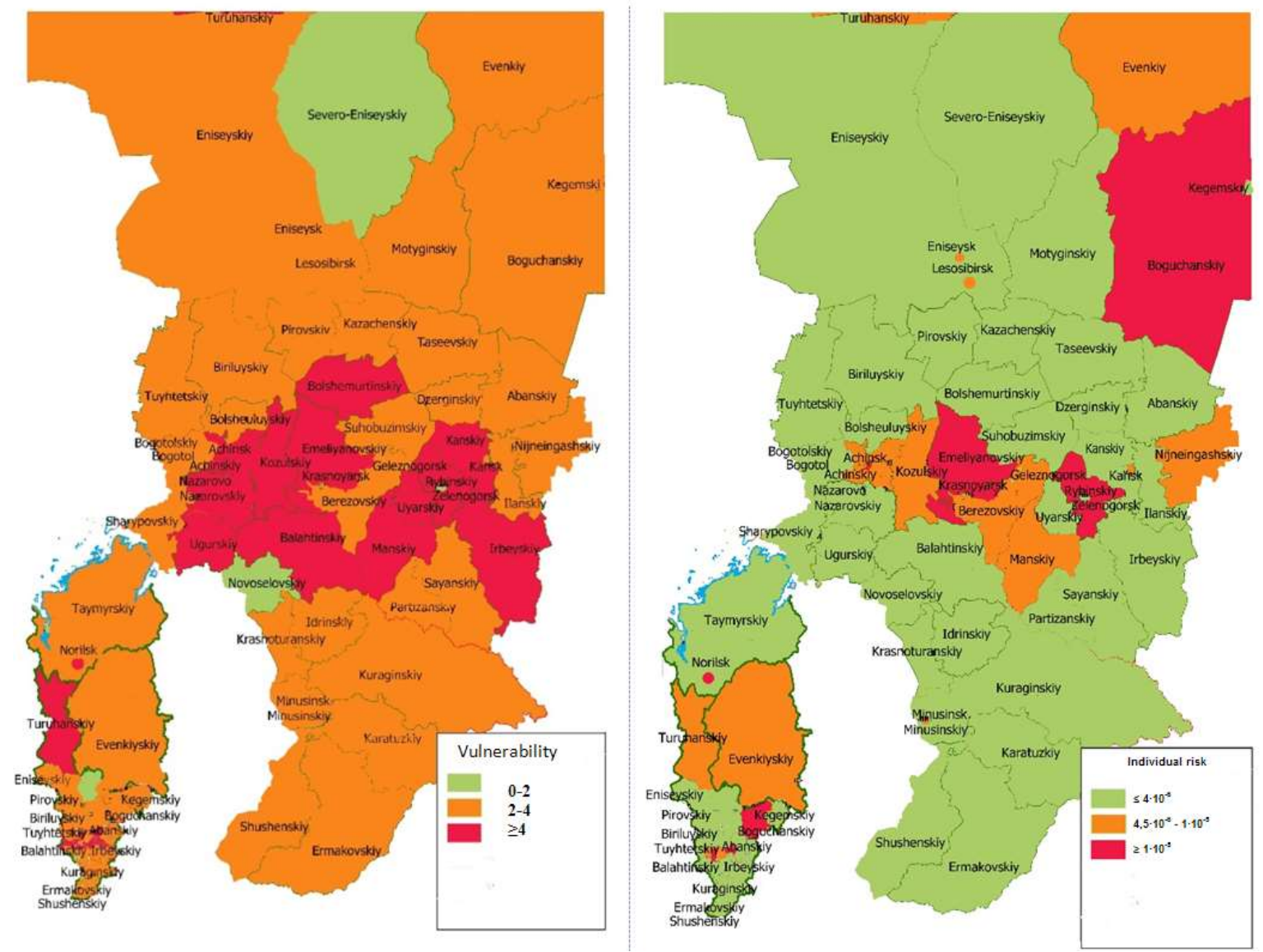

Fig. 1 - Vulnerability of the area and individual technogenic risk for the Krasnoyarsk territory

The event Second Eurasian Risk 2020 Conference and Symposium "Innovations in minimization of natural and technological risks" was funded by Krasnoyarsk Regional Fund of Science. 